Failure to Fail? Practice Educators' Emotional Experiences of Assessing Failing Social Work Students.

Dr Jo Finch

Senior Lecturer in Social work

School of Education and Communities

University of East London

Water Lane

Stratford

E15 4IZ

Tel: 02082232932

Email: J.Finch@uel.ac.uk

Professor Imogen Taylor

Head of Social Work

School of Education and Social Work

Essex House

Falmer

East sussex

BN1 9QQ

Tel: 01273872511

Email: I.J.Taylor@sussex.ac.uk 


\title{
Failure to Fail? Practice Educators' Emotional Experiences of Assessing Failing Social Work Students.
}

\begin{abstract}
The paper explores issues that arise in the assessment of failing social work students in practice learning settings in England. It draws on existing literature on the topic, as well as a small empirical study. The qualitative methodology is influenced by practitioner-research paradigms. Based on twenty in-depth interviews with practice educators, the research utilised the voice-centred relational method of data analysis which revealed five distinct "emotional stories", explaining why practice assessors' found the process of working with a failing student challenging and difficult. These stories include the "guilty story", "angry story", the "what is my role story", the "idealised learner story, and the "internalisation of failure so I couldn't always fail them story". The paper considers the possible adverse impact on the assessment process of these often unacknowledged emotional responses experienced by practice educators, namely, that there is a very real possibility that students are being passed as competent when the evidence may strongly suggest otherwise. The paper offers some ways forward in light of the findings, linking these to the change process underway in social work education in England but suggesting these have wider relevance to practice assessment in other contexts.
\end{abstract}

Key Words: Failing Students, Practice Education, Practice Assessing, Practice Learning, Placements, Assessment of Practice. 


\section{Failure to Fail? Practice Educators' Emotional Experiences of Assessing Failing Social Work Students.}

\section{Introduction}

In 2009, the Social Work Task Force (SWTF), established in England, undertook a comprehensive review of frontline social work practice and made recommendations for improvement and reform. It's' Interim Report, aptly named 'Facing up to the task' indicated:

'Specific concerns have been raised about the ...robustness and quality of assessment, with some students passing the social work degree who are not competent or suitable to practise on the frontline' (SWTF, 2009, p. 24).

Concerns about the failure of the profession to deal with suitability in practice have been raised by employers and governments in England throughout the first decade of this century although there have been concerns about aspects of placements for a number of years. These concerns centre on the quality and quantity of placements (Sharp and Danbury, 1999; Kearney, 2003; Skills for Care, 2006), and the rarity of placement failure, both in the UK and internationally (Williamson et al., 1985; Coulshed, 1980; Hughes and Heycox, 1996, Raymond, 2000; Basnett and Shepherd, 2010). A related issue is that practice assessors appear to find the process of failing a student extremely stressful (Bogo et al., 2007; Basnett and Shepherd, 2010; Schaub and Dalrymple, 2011). A possible consequence is that failing students are passed, despite concern about their performance. Similar concerns are found in other disciplines, for example, occupational therapy (Ilot and Murphy, 1997), nursing (Lankshear, 1990; Duffy, 2004), teaching (Knowles et al, 1995), and counselling psychology (Vacha-Haase et al., 2004; Hoffman et al, 2005; Johnson, 2007).

Precise numbers in relation to placement failure are hard to come by. In England in 2003/2004, 2.6\% of social work students failed a placement (GSCC, 2007a, 2007b). More recently the failure rate in 2006/2007 stood at 
$3.2 \%$ (GSCC, 2008), and 2.5\% in 2008-9 (GSCC, 2010), although these figures refer to failure across a programme rather than just the placement element. The figures under-represent issues of lack of competence or unsuitability as some students will voluntarily withdraw from programmes before they reach a fail assessment.

The research study at the heart of this paper was part of a doctoral study which moved from an initial deductive focus on placement failure, to an inductive focus on why some practice educators appear to find failing students so difficult. To examine this shift, we locate the issue within the changing policy context over the decade. We then review literature relevant to this topic in social work and related fields. The focus then moves to the key empirical findings from the study, completed in 2010, which are further explored in light of the earlier the literature review. Finally, we highlight possible ways forward in relation to the training and support of practice assessors to equip them for their gatekeeping task of preventing potential harm to service users.

First, in recognition of an international readership, terms need to be clarified. The term 'practice assessor' is used as it was current in England when the empirical study was undertaken. The term 'practice educator' has since emerged in England, perhaps reflecting the importance of emphasising learning as well as assessment. Internationally, we are aware that other terms are in use, for example, 'field instructor' has been in use for decades in the USA and Canada.

\section{The changing policy context of practice assessment}

It is notable that in the first decade of the $21^{\text {st }}$ century in England, there have been two iterations of major changes in social work education, both of which aim to improve standards in education and practice, and have given preeminence to practice learning. 
In 2003, there were several significant changes introduced in tandem, designed to improve the quality of social work practice. The Care Standards Act (2000) saw the General Social Care Council (GSCC) established to monitor and regulate social work education and training, and 'social worker' was established as a protected title. The social work degree replaced the former qualification, the Diploma in Social Work. Reasons for its introduction included the need to develop public trust and confidence in the profession; transform its' status and image and ensure social work training was on a similar level to comparator professions (Department of Health, 2004; Orme et al, 2009). Furthermore, its aim was to improve practice; with enhanced importance to be given to practice learning, and the required number of assessed days in practice at both undergraduate and masters level, increased from 130 to 200. Practice assessment was to focus on evidencing how the student met the key roles set out in the new National Occupational Standards for Social Work (Training Organisation for Personal Social Services, 2002).

In 2009, following intense media criticism triggered by a child abuse death, the Labour government set in train the second major overhaul of social work education. It established the Social Work Taskforce which in its final report (2009) included a recommendation for a single national reform programme of social work to be overseen by the Social Work Reform Board (SWRB). In 2010, the new Coalition Government adopted the work of the SWRB, and further changes continued to reflect a focus on practice assessment. Key to these, the new College of Social Work (TCSW) launched a Professional Capability Framework (PCF), and the Health Professions Council (HPC), which in the second part of 2012 will take over the regulatory functions of the GSCC, will replace the National Occupational Standards with a competence framework known as Standards of Proficiency. These changes will form the backbone for regulation and provide the basis for social work accountability for the foreseeable future.

Also in the name of enhancing standards, continuing professional development awards, including the Practice Teaching Award, were substantially revised (GSCC, 2005; GSCC, 2006) in 2007 and became post 
graduate qualifications. In 2010, the SWRB piloted new practice educator frameworks, due to be implemented in 2013. In brief, practice educators, will be required to have undertaken a two stage qualification (TCSW 2012).

\section{Literature review of placement failure}

The initial focus for searching the literature was 'assessing failing social work students', drawing predominantly on UK literature going back to the mid 1990's when an earlier set of changes to UK social work education were introduced, and including earlier texts if they had been influential. Australian and North American resources were accessed where available. In the following discussion, the nationality of the authors is indicated where they are not from the UK context. Searches indicated that relevant texts were limited in the area of failing students. There was also very little guidance on managing difficult placement situations or failing students. Indeed, there is still only one UK book (now out of print) on managing failing students in practice learning settings (Sharp and Danbury, 1999), and two UK articles from a tutor's perspective about managing placement difficulties (Burgess et al., 1998a; Burgess et al., 1998b).

Given the paucity of UK social work literature, literature on assessing failing students was searched in comparator professions. The nursing literature explored the challenges in failing students on clinical placements (Lankshear, 1990; Duffy, 2004). Teaching (Knowles et al, 1995), occupational therapy (llott and Murphy, 1997) and counselling psychology (Vacha-Haase et al, 2004; Hoffman et al, 2005; Johnson, 2007;) revealed similar concerns around difficulties in failing students on placement. Indeed, the term 'failure to fail' (Duffy, 2004; Shapton, 2006) emerges in a number of professional contexts. Analysis of the literature suggests there are five key themes in practice assessors' experiences of the challenge in failing students.

First is a concern about practice assessors' lack of understanding and inappropriate application of the assessment framework (Williamson et al., 1985; Walker et al., 1995; Hughes and Heycock, 1996) and linked to this; 
procedures not being followed correctly (Burgess et al., 1998a, 1998b; llott and Murphy, 1997; Duffy, 2004; Kaslow et al., 2007). Associated lack of support or clear guidance from the university was also found to be a factor (Burgess et al., 1998a, 1998b; Vacha-Haase, 2004).

Second, the fear of litigation is significant, especially in the North American context (Cole, 1991; Cole and Lewis, 1993; Raymond, 2000; Royse, 2000). Urwin et al (2006) provide a useful summary of various American legal precedents that relate to social work education and stress the importance of due process. Vacha-Haase et al (2004) found that the fear of litigation was significant in decision making in relation to failing students in counselling psychology. There is limited UK research about the impact of fear of litigation on assessment decisions.

Third, the notion of role confusion or role strain (Fisher, 1990; Proctor, 1993; Owens, 1995; Cowburn et al, 2000; Vacha-Haase et al, 2004; Currer and Atherton, 2007) emerged strongly as a factor in making it difficult to fail students. This literature suggests that that the practice assessor role encompasses potentially conflictual roles, specifically nurturer and enabler of learning on the one hand and assessor and manager on the other. Within the supervision literature the issue of the dilemmas and tensions that arise when one occupies multiple roles has been well documented (Pritchard, 1995; Feasey, 2002). Shardlow and Doel (1996) argue that if practice assessors view the assessment process as part of an on-going educational process, then there may be a lack of acknowledgement of the assessor/manager role and an unwillingness to fail students. This issue emerged strongly from the empirical work undertaken and will be explored later.

The fourth theme concerns the difficulty in defining minimum standards of practice (Sharp and Danbury, 1999; Lafrance et al, 2004; Skinner and Whyte, 2004; Finch, 2010) and the question of what is "good enough"? For example, what is good enough in one agency might not be considered good enough in another; and the gap between being good enough to meet the competency requirements but not good enough for qualified practice. 
The final theme concerns the emotional responses of the practice assessor to working with failing students. The emotional pain when failing a student in practice has been noted in a range of professional contexts. North Americans, Bogo and colleagues (2007) for example, commented on the considerable emotional difficulties experienced by social work practice assessors when having to give negative feedback and assess competence. Gizara and Forrest (2004) explored supervisors' narratives of failing counselling psychology students and reported that the experience for supervisors was "horrible...painful...very sad...a gut wrenching experience" (2004:136). In a similar vein, Samac (1995) describes the guilt, anger and shame felt by clinical supervisors of psychotherapy students when failing their work. A hope that the deficiencies or problems would sort themselves out was found among psychology assessors (Good et al., 1995; Floyd et al., 1998; Hoffman, et al., 2005). A phenomena, known as the "rule of optimism", mostly found in the context of child protection work (Dingwall et al., 1983), also emerged in studies of psychology supervisors (Good et al., 1995; Hoffman, et al., 2005) where student positives were over emphasised and concerns under emphasised or ignored. We will return later in the paper to the emotional responses of the practice assessors.

\section{Research methodology and method}

Methodologically, the study design was qualitative and influenced by ethnographic, narrative and life story approaches, selected as the most appropriate for exploring narratives of practice (Everitt and Hardiker, 1996; Shaw and Gould, 2001). It also accommodated the changing focus from initial concern about a possible failure to fail in practice learning settings, to a more exploratory, theory building approach. As the interviews commenced, a researcher-practitioner paradigm was made explicit, reflecting the researcher's multiple roles, i.e. practice assessor, tutor and doctoral researcher. Twenty interviews with practice assessors were undertaken which aimed at encouraging the participants to tell their stories. The sampling was purposeful and respondents invited to participate on the basis that they 
had worked with a struggling or failing student. Participants were recruited via direct approaches or through contacts and were given full details about the research with time to make an informed decision as to whether to take part. They were drawn from ten universities, mostly around London but also in the North and South of England, and from a wide range of practice settings.

Ethical standards and guidelines of the university where the doctoral researcher was registered were adhered to, however, the emotionally charged tone of the interviews, as will be later seen, was unanticipated, raising ethical dilemmas and tensions as the research progressed (Finch, 2009). Strongly expressed views emerged as potentially at odds with social work values and acceptable standards of professional discourse, although it felt important to explore the emotionality rather than be distracted by the surface content. Some interviews also revealed poor assessment practice, raising further

ethical dilemmas for the researcher-practitioner. Support was offered to research participants at the time of the interview and in follow up emails. The implications of these emotional discourses will be discussed in the conclusion.

The data was analysed using the voice-centred relational method (Gilligan, 1982: Brown and Gilligan, 1992), a framework for analysing written text by undertaking four distinct readings. This appeared to fit well with the qualitative approach and had resonance with social work values. There is a lack of guidance in the literature about how to integrate the four readings into a final analysis. In this study, this was achieved by categorizing the emotional content thematically across all the readings into the following stories where respondent's names have been changed and identifying data removed.

\section{The Findings}

\section{The Guilty Story}

The experience of working with a marginal, struggling or failing student caused the practice assessor a great deal of guilt. Daisy talked about the guilt "setting in" the moment she heard the tutor mention the word "failure": 
...because at that time I made the decision [to fail the student], the guilt, it was unbearable...it was a reality check and I don't know what's going on with her but all | know is that everyone else in her year were out on their placements and she's not but at the end of the day it was her livelihood, it could have been the end of her career, oh my god, what about her children? I felt like I am a rotten shit.

Emily, an experienced children and families social worker described the experience of failing the student as "worse than removing somebody's child". Claire also stated:

...it was the first fail, I felt terribly guilty, ...I had sleepless nights, felt quite sick...I felt incredibly guilty.

Practice assessors also expressed guilt when they reflected on previous students whom they should have failed. Patricia lamented not being able to manage the situation with the student and Lily discussed not failing a particular student as "...the worse career decision I have ever made." The feelings of guilt that emerged may have contributed to practice assessors becoming angry.

\section{The Angry Story}

The experience of working with a failing student caused some practice assessors to feel intense anger towards the student and the university. Daisy for example, was particularly angry when she recounted the story of the failing student who was in placement for only seven days. The account was noticeable in that Daisy complained bitterly about the student's unprofessional behaviour and conduct, yet Daisy's conduct in the interview was stark in its aggressive style, student blaming discourse and unprofessionalism. Daisy recalled the student claiming her inappropriate behaviour was due to her menstruating,

...I just thought...I thought, 'Fuck You'! You are not going to apologise for your fucking behaviour with a period. Every fucking woman in the world gets a period, yes some 
have difficulties, some get emotional...your deafness didn't wash so now you've like resorted to like, fucking bottom of the barrel...

Daisy later fantasised about service users telling the student to "fuck off" and addressing the student as "a fat fucking bitch". Daisy veered between extreme anger and guilt. Lily too, expressed anger and described a student in a less than professional way:

...she was absolutely terrible, she was appalling, she was abysmal and no way should she ever be near clients...there were a million difficulties with her...she was incredibly arrogant and rude... she was also very aggressive.

Tim was also angry in his narrative and described the student as:

...poisonous...he was venomous...he was a flipping nightmare.

A number of practice assessors were able to explicitly articulate their feelings of anger towards the student. For example, Claire, in relation to a student she had failed, stated:

...I was really pissed off with him, I felt angry...the guy out of all of them, I felt angry...

Jenny also expressed anger towards her student as she felt:

...like I was working harder than him in his practice placement.

Jenny recognised the dynamics that had emerged between herself and the student; that she was in rescuing mode which caused the student to take even less responsibility for his learning; yet could not escape from this dynamic which increased her levels of anger and frustration.

Anger was also expressed towards the university and the university tutor. Practice assessors spoke of feeling intimidated by the university and that 
universities were not open to hearing concerns about the students. Katie for example states:

So I went and had a meeting at the university after things had broken down to discuss it... they were only interested in what he [the student] had to say. And in fact when they sent a report, I wasn't prepared to sign the report they had sent because it didn't stress or recalled any of the concerns I had raised.

Katie believed that "the university didn't want to hear at all". Alongside the "not hearing", practice assessors also spoke of a feeling that the university did not want them to fail students. Susan spoke of a "surreptitious discouragement of failure" and Lily felt that the university was not open to the possibility of failing students in placement because of the need to "preserve its red brick status". Martha, in her narrative, felt that the tutor had a positive view of the student and so was not taking her concerns seriously,

...we had such...difference of opinion that I really questioned my own judgment because I thought actually, this is somebody who has, you know, twenty years of teaching....and I seem to be the only one who thinks there's a problem...he doesn't seem to think there is a problem with this student. I must admit, I really felt the college did not want to fail this person.

Practice assessors also expressed anger that the universities had taken on poor quality students, were more interested in reaching their recruitment targets and hid negative information about students that had emerged in previous placements. A further explanation for the emergence of the anger might rest on the difficulties practice assessors had in understanding and reconciling the complex nature of their roles. This leads on to the "what is my role story?"

\section{What Is My Role Story?}


It seemed that some practice assessors struggled with the role. In particular, combining the nurturer-enabler and the assessor roles caused some distress. Lily for example, expressed this explicitly:

...there was a clash for me between the facilitator of learning role and the kind of management role....now when I was a facilitator of learning, I felt very nurturing...I respond really well to people who enjoy learning but the flip side of that was when I had to become the kind of teller-off or the person who was making judgments about somebody, I did struggle with that....

It appears that Lily could not bring these two elements together. There was evidence that practice assessors who had managed to bring together these two aspects of the role, were able to explicitly articulate their role, and could subsequently go on to fail a student without experiencing the levels of distress experienced by other practice assessors. Peter for example, could clearly articulate his role and did not see it as inherently conflictual, furthermore, he was clear about the division of responsibilities:

...you know it's meant to be a mature student I am dealing with...we are entering into this arrangement, right, as adults, you know I had my part to play, the student has their part.

Peter understood that as a practice assessor he may well be confronted with a failing student and required to respond appropriately. Andrew, for example recognised that in working with a student:

...you can sometimes be drawn into that role, often as a rescuer....at the same time you can be perceived as a persecutor and it all can get very complicated which is where I rely, very much on my own boundaries, establishing these boundaries at the beginning...you are not there to heal, you're here to learn.

It was notable that very few practice assessors in the research, explicitly discussed their role as a gatekeeper. Peter acknowledged his ultimate responsibility to protect service users and only Emma, talked explicitly about 
"passing through the gate", although the fact that there were other gates for the student to go through was influential in her decision to suggest the student redo a placement rather than fail her. The distressing levels of guilt and anger felt by some practice assessors were also possibly as a result of "the idealised learner story".

\section{The Idealised Learner Story}

Practice assessors expressed narratives about the "ideal learner" in which when there was a gap between the practice assessors' initial fantasy of the student and what the student was actually like; this resulted in anger and guilt. Jennifer for example, compared the student's approach to learning with her own as a student:

...the students on my course were much more passionate. When we wasn't on placement or at college in the day time, we'd be on the phone all night about social work. It was like the core of our beings...I didn't feel that level of passion with my student, I never felt that passion, that motivation.

Tracy also compared her behaviour as a student with her social work student. She had clear expectations of the student prior to the placement commencing,

I was thinking that.... am going to have a student that will take responsibility....that was my fantasy that I was going to have somebody that would just, you know, kind of gel, adapt to the team...and another big expectation...that's she's coming with a variety of knowledge...up to date.

Practice assessors raised concerns about what they perceived as "passive learners" although whilst some practice assessors, including Peter and Andrew, managed this dynamic appropriately, others became caught up in the rescuing role and began to take responsibility for their student's failure. The gap between expectations and reality may impact adversely on the assessment process and it seemed that the focus of the practice assessor's intervention centred on making the student the "ideal learner" rather than on 
undertaking a realistic assessment of the student's competence. This leads on to the final story.

\section{The Internalising Failure so I Couldn't Always Fail Them Story}

The guilt, anger, disappointment and perhaps role strain felt by some practice assessors when the student did not become a "good learner", appeared to prompt some practice assessors to internalise the students failings as their own. The practice assessor makes an emotional investment in the student which once made, cannot be let go. Any subsequent failure on the student's part then becomes heavily internalised by the practice assessor and the "fault" becomes his or her own. Martha for example, states this explicitly:

I actually felt that it was my failing because I wasn't getting it [evidence] out of her.

Practice assessors questioned whether they could have done something differently, whether they had made a mistake, not given the student enough time or just not managed the situation well. Patricia was critical about her performance:

...I should have been clearer all the way through that I have more concerns about her than I was...and so I felt I hadn't supervised her enough...I hadn't done my job how it was meant to have been done.

Terry was clear that a student's failure was directly related to the practice assessor,

So I think for someone to fail, there had to be failure on both, most of the time there has to be failure on both parts. I mean that puts a lot of responsibility on the practice teacher but for you to somehow justify that you have done as much as you can...I would say that $90 \%$ of the time if the students fails, there's something wrong with the practice assessor.

Terry in his narrative, described strong evidence of the student's inability to make the necessary development, yet passed her. He appeared not to be 
able to let go of his theory of the connection between the student failing and the practice assessor failing.

Another facet to this story, concerned practice assessors' almost intuitive worry about the student from the initial meeting. Peter for example, expected the student to be more enthusiastic. He commented on his "gut feeling" of "serious doubts" about the placement being successful. Martha too, experienced this phenomenon at the initial interview:

I remember thinking...this woman is going to struggle in this environment...I didn't feel I wanted to take her on.

There is a sense of regret in the narratives that practice assessors did not take account of their gut instincts and then spent some of the placement trying to over compensate, although both Peter and Martha went on to fail these students. For Martha, the guilt and over compensation meant the placement went on for longer than it should. There is a real possibility, that by internalising the student's failure as their own, practice assessors may be unable to fail a student when required.

\section{Discussion of Findings}

The key message to emerge from all the stories is that working with a struggling or failing student can potentially invoke intensely uncomfortable feelings in a practice assessor. This has the potential to obscure the assessment process to the point that some social work students are being passed inappropriately. The research accords with the existing literature that focuses on the emotional pain involved in failing a trainee (Samac, 1995; Gizara and Forest, 2004; Bogo et al, 2007); explicitly names the emotional distress, anger and guilt and highlights particular psychological processes that might contribute further to the emotional distress, including: internalising the students failure as their own; having particular expectations about the student as a learner; and, struggling to reconcile the multiple roles inherent in the practice educator role. Indeed, these psychological processes emerged 
strongly in previous studies. The emotional difficulties in failing a student may offer one explanation as to why there is a low failure rate in practice learning settings.

The implications for practice education are quite significant. One practice assessor admitting to making an error in not failing a particular student; and stated, "it was the worst career decision I have ever made". There were also a number of examples of assessment decisions being made, that in light of the story told about the student and their inadequacies, appeared to be of concern in that they were assessed as competent and passed.

A student failing or struggling in a placement is likely to be experiencing a range of uncomfortable and difficult emotions, namely anger, guilt, confusion and distress and psychodynamic frameworks offer a potentially useful theoretical position to help practice assessors make sense of uncomfortable projected feelings, in a context of competing responsibilities and attempts to reconcile and make sense of care and control issues. Mattinson (1992) points out the need for reflective practitioners who can make sense of, and understand the dynamics that have been created. When practice assessors react to the uncomfortable and distressing emotional climate that has emerged, it seems that there is a missed opportunity to use these feelings to firstly consider how the student might be feeling, which could help the student in their development and learning, and secondly, to reflect on the triadic dynamics that emerge in relation to the student and the university tutor. An understanding of transference and counter transference, and reflection on the feelings could help contain the situation and benefit the student, practice assessor, university tutor, and ultimately service users.

\section{Concluding Comments}

There were clear limitations to this study. First and most notably it was smallscale and qualitative, making generalisations not possible. Second, the interviews took place between 2005 to 2007 and it could be argued that the 
possible positive impact of the changes to the post qualifying frameworks introduced in England in 2007 could not therefore be adequately represented. Third, it could be argued that the participants chose to be involved in the research biasing the results towards those whose experience had been challenging and unpleasant. Fourth, the research focused on the practice assessor yet the relationship is a triadic one between the practice assessor, student and tutor and there is a need to explore these different perspectives.

In spite of the above limitations, the results from this small-scale study are original and suggest that emotional factors are significant in practice assessors' decision making processes in relation to passing or failing social work students. As we have seen, the research indicated that there may be a reluctance to fail social work students because of the uncomfortable and difficult feelings evoked by these situations. Four key issues arose from the study that would benefit from further research and consideration.

First the potential value of assessment frameworks is indicated, to aid practice assessors in undertaking an appropriate assessment. The research demonstrated however that a nationally agreed assessment framework in place in England, cannot guarantee protection of practice assessors from uncomfortable feelings, or make it "easier" to fail students.

Secondly, the study confirms the need for practice assessors to be appropriately trained to clearly understand their role. Of particular note, education and training must address the potential for role conflict and the challenge of reconciling the roles of nurturer/enabler and assessor/manager, and how to manage this in practice.

Third, the study confirms the need for support for all practice assessors and particularly for those working with struggling or failing students. This support clearly should come from the existing structures of support and supervision within agencies, as well as from the universities. This is particularly important for freelance or independent practice assessors. 
Finally, and most significantly, the study identifies new knowledge about the strong, uncontained and angry feelings which emerged in some practice assessor's accounts. On the surface they appear to evidence lack of professionalism, yet we suggest it reveals the need for reflective practitioners who can be supported to make sense of the complex processes they are engaged in, and respond more appropriately to the intense feelings that are likely to emerge. This also has implications for practice when working with service users who may be experiencing intense emotional distress and clearly require a reflective rather than a reactive, unprofessional response.

Current developments within social work and social work education in England emphasise the need to raise professional standards and conduct as well as promote confident decision making (Munro, 2010). As discussed earlier, the SWRB recommendations have been accepted by the new College of Social Work. The new proposed practice educator frameworks, with a two part qualification aim at setting clear expectations for practice educators and enhancing the quality of continuing professional development and so should go some way to addressing the issues raised in the findings. Finally, universities must develop robust processes to manage situations where there are concerns about practice education which might lead to students being passed who are not yet competent.

\section{Bibliography}

Basnett F., and Sheffield D., (2010) The Impact of Social Work Student Failure upon Practice Educators, British Journal of Social Work, 40, pp 21192136 
Bogo, M., Regher, C., Power, R. And Regher, G. (2007) When Values Collide: Field Instructors Experiences of Providing Feedback and Evaluating Competence. The Clinical Supervisor, 26 (1/2), pp.99-117.

Brandon, J. and Davis, M. (1979) The Limits of Competence in Social Work; The Assessment of Marginal Students in Social Work Education, British Journal of Social Work, Vol. 9, pp 295-347

Brown, L. M. and Gilligan, C. (1992) Meeting at the Crossroads: Women's Psychology and Girl's Development, Cambridge, MA, Harvard University Press.

Burgess, R., Phillips, R. and Skinner, K. (1998) Practice Placements that go wrong. Journal of Practice Teaching, 1, pp 48-64

Burgess, R., Campbell, V., Phillips, R. and Skinner, K. (1998) Managing Unsuccessful or Uncompleted Placements. Journal of Practice Teaching, 7, pp 4-12.

Cole, B. S. (1991) Legal Issues Related to Social Work Program Admissions. Journal of Social Work Education, 27 (1) pp 18-24.

Cole, B. S. and Lewis, R. G. (1993) Gatekeeping Through Termination of Unsuitable Social Work Students: Legal Issues and Guidelines. Journal of Social Work, 29 (2) pp 65-73

Coulshed, V. (1980) Why is Placement Failure so Rare? Australian Social Work, 33 (4), pp.17-21.

Cowburn, M., Nelson, P. and Williams, J. (2000) Assessment of Social Work Students: Standpoint and Strong Objectivity. Social Work Education, 19 (6), pp.627-637 
Currer, C. and Atherton, K. (2007) Suitable to Remain a Student Social Worker? Decision Making in Relation to Termination of Training. Social Work Education, iFirst article, pp.1-14.

Department of Health (2004) First Annual Report - Practice learning Taskforce, London, HMSO

Dingwall, R., Eekelaar, J. and Murray, T. (1983) The Protection of Children: State Intervention and Family Life, Oxford, Blackwell

Duffy, K. (2004) Failing Students. London, Nursing and Midwifery Council.

Everitt, A. and Hardiker, P (1996) Evaluating for Good Practice, London: Palgave Macmillan

Feasey, D. (2002) Good Practice in Supervision with Psychotherapists and Counsellors, London: Whurr Publishers

Finch, J (2009) [un] covering bad practice - story telling or collusion, Student Doctoral Conference, University of Sussex, Falmer, 24th June 2009

Finch, J. (2010) Can't Fail, Won't Fail - Why Practice Assessors Find it Difficult to Fail Social Work Students. A Qualitative Study of Practice Assessors Experience of Assessing Marginal or Failing Social Work Students, University of Sussex, Professional Doctorate in Social Work.

Fisher, T. (1990) Competence in Social Work Practice Teaching. Social Work Education, 9, pp 9-25

Floyd, M. R., Myszaka, M. T. \& Orr, P. (1998) Licensed Psychologists' Knowledge and Utilization of a State Association Colleague Assistance Committee. Professional Psychology: Research and Practice, 29, pp.594-598. 
Furness, S. and Gilligan, P. (2004) Fit for Purpose: Issues from Practice Placements, Practice teaching and the Assessment of Student's Practice. Social Work Education, 23, pp 465-479.

Gibbs, P (1994) Screening Mechanisms in BSW Programs, Journal of Social Work Education, 30 (2) pp.63-75

Gilligan, C. (1982) In a Different Voice: Psychological Theory and Women's Development, Cambridge, Harvard University Press

Gizara, S. S. and Forrest, L. (2004) Supervisors' Experiences of Trainee Impairment and Incompetence at APA-Accredited Internship Sites. Professional Psychology: Research and Practice, 35 (2), pp.131-140

Good, G. E., Thorenson, R. W. \& Shaughnessy, P. (1995) Substance Use, Confrontation of Impaired Colleagues, and Psychological Functioning Among Counselling Psychologists: A National Survey. The Counselling Psychologist, 23, pp.703-721

GSCC (2005) Post-Qualifying Framework for Social Work Education and Training. London, GSCC

GSCC (2006) Specialist Standards for the Requirements for Post Qualifying Social Work Education and Training - Practice Education. London, GSCC

GSCC (2007a) Data Pack 2006-2007 - Social Work Education and Training Statistics. London, GSCC.

GSCC (2007b) Social Work Education in England: Delivering Quality, Recognising Success. The 2007 Social Work Education Quality Assurance Report. London, GSCC. 
GSCC (2008) Raising Standards; Social Work Education in England, London, General Social Care Council

GSCC (2010) A Report on Social Work Education in England, 2009-10, London, General Social Care Council.

Harris, V. and Gill, M. (2007) Practice Learning in Context in Lymbery, M. and Postle, K (Eds) Social Work - a Companion to Learning, London, Sage

Hoffman, M. A., Hill, C. E., Holmes, S. E. and Freitaz, G. F. (2005) Supervisor Perspective on the Process and Outcomes of Giving Easy, Difficult, or No Feedback to Supervisees. Journal of Counselling Psychology, 52 (1), pp.3-13

Hughes, L. and Heycox, K. (1996) Three Perspectives on Assessment in Practice Learning. IN Doel, M. and Shardlow, S. (Eds.) Social Work in a Changing World - An International Perspective on Practice Learning. Aldershot, Arena (Ashgate).

Ilott, I. and Murphy, R. (1997) Feelings and Failing in Professional Training: the assessor's dilemma. Assessment and Evaluation in Higher Education, 22, pp 307-316.

Johnson, B. W. (2007) Transformational Supervision: When Supervisors Mentor. Professional Psychology: Research and Practice, 38 (3), pp.259-267.

Kaslow, N. J., Forrest, L., Van Horne, B. A., Huprich, S. K., Pantesco, V. F., Grus, C. L., Miller, D. S. S., Mintz, L. B., Sschwartz-Mette, R., Rubin, N. J., Elman, N. S., Jacobs, S. C., Benton, S. A., Dollinger, S. J., Behnke, S. H., Shealy, C. N. and Van Sickle, K. (2007) Recognizing, Assessing, and Intervening with Problems of Professional Competence. Professional Psychology: Research and Practice, 38 (5), pp.479-492 
Knowles, J. G., Skrobola, N. L. M. and Coolican, M. J. (1995) We watched them "fail": university supervisors perceptions of "failure" in student teaching. Qualitative Studies in Education, 8, pp.149-170.

Kearney, P. (2003) Framework for Supporting and Assessing Practice Learning. London, Social Care Institute for Excellence.

Lafrance, J., Fray, E. and Herbert, M. (2004) Gate-Keeping for Professional Social Work Practice. Social Work Education, 23, pp.325-340

Lankshear, A. (1990) Failure to Fail: The Teacher's Dilemma. Nursing Standard, 4, pp.35-37.

Mattinson, J. (1992) The Reflection Process in Casework Supervision, London: Tavistock Institute of Marital Studies

Munro, E. (2010) The Munro Review of Child Protection. Final Report - A Child's Centred System, London, Department of Education

New College of Social Work (2012) Practice Educator Professional Standards and Guidance, London, NCSW, http://www.collegeofsocialwork.org/uploadedFiles/TheCollege/ CollegeLibrary /Reform resources/Practice-EducatorProfessional(edref11).pdf $\quad$ (accessed 6/6/12)

Orme, J., Maclntyre, G., Green Lister, P., Cavanagh, K., Crisp, B., Hussein, S., Manthorpe, J., Moriarty, J., Sharpe, E., Stevens, M. (2009) What (a) Difference a Degree Makes: The Evaluation of the New Social Work Degree in England, British Journal of Social Work, Volume 39, pp 161-178

Owens, C. (1995) How the Assessment of Competence in DipSW is Changing the Culture of Practice Teaching. Social Work Education, 14. Pp61-8 
Pritchard, J. (1995) Supervision or Practice Teaching for Students in Pritchard, J. (ed) Good Practice in Supervision, London: Jessica Kingsley Publishers

Proctor, A.K (1993) Tutors' Professional Knowledge of Supervision and the Implications for Supervision Practice in Calderhead, J. And Gates, P (Eds) Conceptualising Reflection in Teacher Development, London: The Falmer Press

Raymond, G. T. (2000) Gatekeeping in Field Education. IN Gibbs, P. and Blakely, E. H. (Eds.) Gatekeeping in BSW Programs. New York, Colombia University Press

Royse, P. (2000) The Ethics of Gatekeeping. IN Gibbs, P., Blakely, E.H (Ed.) Gatekeeping in BSW Programs. New York, Colombia University Press

Samac, J.R (1995) Guilt, Anger and Shame: Failing the Psychotherapy Candidate's Clinical Work, The Clinical Supervisor, 13 (2), pp.1-17

Schaub, J. and Dalrymple, R. (2011) "She didn't seem like a social worker": Practice Educators Experiences and Perceptions of Failing Social Work Students on Placements, London, Higher Education Academy

Shardlow. S. \& Doel, M. (1996) Practice Learning and Teaching, Basingstoke, Macmillan Press Ltd.

Shapton, M. (2006) Failing to Fail: Is the Assessment Process Failing the Caring Profession, Journal of Practice Teaching and Learning, 7 (2) pp 39-54

Sharp, M. and Danbury, H. (1999) The Management of Failing DipSW Students - Activities and Exercises to Prepare Practice Teachers for Work with Failing Students, Aldershot, Ashgate. 
Shaw. I. and Gould, N. (2001) Inquiry and Action: Qualitative Research and Professional Practice in Shaw. I. and Gould, N (Eds) Qualitative Research in Social Work

Skills for Care (2006) Practice Learning Taskforce http://www.skillsforcarelondon.org.uk/Member/PracticeLearning/PractceLearni ngTaskforce.aspx accessed 19/4/08. London, Skills for Care (London).

Social Work Taskforce (2009) Facing up to the Task - The Interim Report of the Social Work Taskforce. London, Department of Health, Department for Children, Schools and Families.

Social Work Reform Board (2010) Building a safe and confident future: One year on - Progress report from the Social Work Reform Board, London, Department of Education, accessed 23/5/12 https://www.education.gov.uk/publications/standard/publicationDetail/Page1/D FE-00601-2010

TOPSS (2002) National Occupational Standards for Social Work. Leeds, Training Organisation for the Personal Social Services (TOPPS).

Urwin, C., Van Soest, D. \& Kretzscher, J. A. (2006) Key Principles for Developing Gatekeeping Standards for Working with Students with Problems. Journal of Teaching in Social Work, 26, (1), pp.163-180.

Vacha-Haase, T., Davenport D. S. and Kerewsky, S. D. (2004) Problematic Students: Gatekeeping Practices of Academic Professional Psychology Programs. Professional Psychology: Research and Practice, 35 (2), pp.115122.

Walker, J., McCarthy, P., Morgan, W. and Timms, N. (1995) In Pursuit of Quality: Improving Practice Teaching in Social Work, Newcastle Upon Tyne, Relate Centre for Family Studies, Newcastle Upon Tyne 
Williamson, H., Jefferson, R., Johnson, S. and Shabbaz, A. (1985) Assessment of Practice - A Perennial Concern: A Study of Current Methods, Skills and Knowledge Used by Practice Teachers to Evaluate the Competence of Social Work Students. Cardiff, School of Social and Administrative Studies, University of Wales College of Cardiff, Centre for Social Work Studies 